\title{
HUBUNGAN TUGAS PERAWATAN KESEHATAN KELUARGA DENGAN KEJADIAN PNEUMONIA PADA BALITA DI WILAYAH KERJA PUSKESMAS TINGGEDE KABUPATEN SIGI
}

\section{The Relationship between Family Health Care Duties and the Incidence of Pneumonia in Toddlers in the Working Area of Tinggede Public Health Center in Sigi District}

\author{
Muh. Jusman Rau ${ }^{*}$, Putri Yulianingsih ${ }^{2}$ \\ Jurusan Epidemiologi, Fakultas Kesehatan Masyarakat, Universitas Tadulako, Indonesia
}

*Korespondensi: jusmanepid06@gmail.com

\begin{abstract}
ABSTRAK
Pneumonia merupakan infeksi peradangan pada saluran pernapasan yang menyerang jaringan paru yang ditandai dengan batuk yang disertai napas cepat atau sesak napas. Menurut laporan WHO, sekitar 800.000 hingga 1 juta anak meninggal dunia setiap tahun akibat pneumonia. Tingkat penyebaran pneumonia balita di Indonesia dengan usia 1-4 tahun yaitu berkisar 154 kasus tahun 2019. Di Kabupaten Sigi terdapat Puskesmas Tinggede yang memiliki kasus pneumonia sebanyak 53 kasus. Tujuan penelitian ini untuk mengetahui hubungan Mengenali Masalah, Mengambil Keputusan, Merawat Anggota Keluarga, Memelihara Lingkungan Rumah Dengan Kejadian Pneumonia Pada Balita di Wilayah Kerja Puskesmas Tinggede Kabupaten Sigi. Penelitian ini menggunakan desain penelitian cross sectional study. Perhitungan sampel mengunakan rumus Slovin dengan jumlah sampel 93 Responden. Analisis data dilakukan secara univariat dan bivariat menggunakan uji chi square. Hasil penelitian menunjukkan terdapat hubungan yang signifikan antara mengenali masalah $(p=0,003)$, mengambil keputusan $(\mathrm{p}=0,005)$, merawat anggota keluarga yang sakit $(\mathrm{p}=0,001)$, memelihara lingkungan rumah $(\mathrm{p}=0,001)$ dengan kejadian pneumonia pada balita. Dalam tugas perawatan kesehatan keluarga, keluarga perlu memahami informasi mulai dari penyebap dan gejala pneumonia. Mampu mengambil keputusan alternative pengobatan seperti ke rumah sakit, puskesmas, atau kedukun. Merawat anggota keluarga seperti memberikan kompres saat anak demam dan memberikan obat dengan resep dokter, memelihara lingkungan rumah dengan memperhatikan syarat rumah sehat.

Kata kunci: Tugas Perawatan kesehatan keluarga, pneumonia.
\end{abstract}

\section{ABSTRACT}

Pneumonia is an inflammatory infection of the respiratory tract that attacks lung tissue characterized by coughing accompanied by rapid breathing or shortness of breath. According to a WHO report, around 800,000 to 1 million children die every year from pneumonia. The rate of spread of pneumonia under five in Indonesia with ages 1-4 years is around 154 cases in 2019. In Sigi District, there is the Tinggede Public Health Center which has one of the highest cases of pneumonia, 53 cases. The purpose of this research is to determine the relationship between recognizing problems, making decisions, caring for family members, caring for the home environment and the incidence of pneumonia among toddlers in the working area of the Tinggede Public Health Center, Sigi District. This research used a cross sectional study design. The sample collection used the Slovin formula with a sample size of 93 respondents. Data analysis was performed univariate and bivariate using the chi square test. The results show that there is a significant relationship between recognizing problems ( $p=$ $0.003)$, making decisions $(p=0.005)$, caring for sick family members $(p=0.001)$, maintaining the home environment $(p=0.001)$ and the incidence of pneumonia in children under five. In family health care duty, families need to understand information starting from the causes and symptoms of pneumonia, able to make alternative treatment decisions, such as going to a hospital, health center, or a traditional healer. Caring for family members such as applying compresses when a child has a fever and giving medicines with a doctor's prescription, maintaining the home environment by paying attention to the requirements of a healthy home.

Keywords: Family Health Care Duty, Pneumonia 


\section{PENDAHULUAN}

Penyakit menular merupakan penyakit yang disebabkan oleh organisme pathogen, seperti virus, bakteri, parasit, atau jamur, dan dapat berpindah ke orang lain yang sehat. Penyakit menular dapat ditularkan secara langsung maupun tidak langsung. Penularan secara langsung terjadi ketika kuman pada orang yang sakit berpindah melalui kontak fisik, misalnya lewat sentuhan dan ciuman, melalui udara, saat bersin, dan batuk, atau melalui kontak dengan cairan tubuh, seperti urine dan darah. Penyakit menular juga dapat berpindah secara tidak langsung. Misalnya saat menyentuh kenop pintu, keran air, atau tiang besi pegangan di kereta yang terkontaminasi. Di Indonesia, penyakit menular yang umumnya terjadi yaitu ISPA, diare, HIV, TB dan penyakit yang di tularkan melalui darah. Bentuk penyebaran yang paling umum termasuk fecal-oral, makanan, hubungan seksual, gigitan serangga, kontak dengan fomites yang terkontaminasi, tetesan, atau kontak kulit. (Anggina \& Lestari, 2019).

Penyakit saluran pernapasan merupakan salah satu penyebab kesakitan dan kematian yang sering menyerang anak-anak di bawah usia 5 tahun (balita) lebih banyak dibandingkan dengan penyakit lain seperti AIDS, malaria, dan campak. Pneumonia ialah suatu proses inflamasi pada alveoli paru-paru yang disebabkan oleh mikroorganisme seperti Streptococcus pneumoniae (paling sering), kemudian Streptococcus aureus, Haemophyllus influenzae, Escherichia coli dan
Pneumocystis jiroveci. Penyakit pneumonia bersifat endemik dan merupakan salah satu penyakit menular yang tersebar hampir di sebagian besar negara berkembang termasuk indonesia dan menjadi masalah yang sangat penting (Widagdo, 2017).

WHO dan UNICEF mengidentifikasi 15 negara dengan jumlah kematian akibat pneumonia dan diare tertinggi pada anak di bawah lima tahun. Untuk semua 15 negara, skor GAPPD Pneumonia lebih besar atau sama dengan skor Diare GAPPD: skor GAPPD Pneumonia median adalah 59\% dan skor Diare GAPPD rata-rata adalah 36\%. Tanzania menduduki peringkat teratas dengan skor GAPPD Pneumonia dan GAPPD Diare tertinggi (masing-masing 78\% dan 63\%); skor GAPPD terendah ada di Chad (masing-masing $25 \%$ dan $12 \%$ ). Tidak satu pun dari 15 negara memenuhi skor target GAPPD Pneumonia dari $84 \%$, dan tiga negara - Nigeria, Chad, dan Somalia - memiliki skor GAPPD Pneumonia di bawah setengah dari skor target (42\%). Indonesia hanya mencapai target skor $65 \%$. (Ceria, 2016).

Pneumonia merupakan penyebab terbesar kematian anak balita di Indonesia. Riset Kesehatan Dasar (Risekdes) tahun 2018, menunjukan insiden pneumonia di Indonesia adalah $61,99 \%$ dan pneumonia berat usia 1-4 thn yaitu 142 kasus. Sedangkan tahun 2019 perkiraan pneumonia 12,504 dengan prevelensi $5,19 \%$ sedangkan pneumonia berat pada usia 1-4 thn yaitu berkisar 154 kasus Sampai saat ini (Kemenkes RI, 2018). 
http://journal.unpacti.ac.id/index.php/JPP

Kasus pneumonia di Provinsi Sulawesi

Tengah pada tahun 2018 berdasarakan cakupan penemuan pneumonia masi belum mencapai target yaitu 85\%, di mana ada sekitar 14 Kabupaten/Kota yaitu Morowali utara 5,9\%, Morowali 16\%, Bangkep 17,1\%, Poso 24,5\%, Touna 42,5\%, Parimo 47,5\%, Banggai Laut 49,5\%, Sulawesi Tengah 60,3\%, Donggala $66 \%$, Sigi 76,7\%, Toli-toli 80,7\%, Buol 81,1\%, Banggai Kepulauan 85,1\%, sedangkan yang telah mencapai target yaitu Kota Palu 93,6\%. Dan pada tahun 2019 Dinkes Provinsi Sulawesi Tengah dengan cakupan penemuan pneumonia di Kabupaten/Kota yaitu dengan target $90 \%$, dari 14 Kabupaten/Kota yaitu Morowali Utara 5,4\%, Morowali 16,2\%, Banggai Kepulauan 19,4\%, Buol 28,8\%, Touna 37,1\%, Poso 40,4\%, Toli-toli 48,6\%. Sigi 50,2\%, Parimo 51,4\%, Sulawesi Tengah $52,3 \%$, Donggala 52,8\%, Banggai Laut 62,4\%, Kota Palu 83,7\%, sedangkan yang telah mencapai target yaitu Banggai 92,8\% (Dinkes Sul-Teng, 2019).

Berdasarakan data di Puskesmas Tinggede Tahun 2018 pada balita usia $1<5$ tahun berjumlah 49 kasus dimana terdiri dari laki 27 kasus dan perempuan 22 kasus. Tahun 2019. Pneumonia kembali meningkat dengan jumlah 53 kasus dengan usia $1<5$ tahun dimana terdiri dari laki-laki 30 kasus, perempuan 23 kasus. Dari data di atas Puskesmas Tinggede memiliki kasus tertinggi Pneumonia bahkan dari 10 penyakit tertinggi yang di antaranya ISPA, Hipertensi, Gastrol, Penyakit Kulit, Diare, Kencing Manis, Penyakit Lain,
Kelainan Syaraf dan Kecelakaan.

Salah satu tugas kesehatan keluarga dalam bidang kesehatan adalah mengenal masalah kesehatan. Keluarga harus mampu mengetahui perubahan sekecil apapun yang dialami oleh keluarga dan mengetahui masalah kesehatan yang dialami seperti faktor penyebab, faktor yang mempengaruhi kejadian pneumonia dan persepsi keluarga terhadap masalah kesehatan yang dialami keluarga (Sitanggang et al.,2016).

Selain itu keluarga juga memiliki tugas mengambil keputusan untuk melakukan tindakan kesehatan yang tepat bagi keluarga. Tugas kesehatan pada tahap ini merupakan usaha keluarga dalam mencari pertolongan alternatif pengobatan yang tepat sesuai dengan keadaan keluarga. Dalam hal ini keputusan yang menyangkut penanganan penyakit Pneumonia dari anggota keluarga harus ditangani di rumah, di sebuah klinik medis atau rumah sakit di mana sikap positif dari keluarga dalam mengambil keputusan yang tepat tentang tindakan yang akan dilakukan kepada anggota keluarga yang sakit akan sangat berpengaruh terhadap proses penyembuhan dan kualitas pengobatan balita yang mengalami Pneumonia (Sitanggang et al., 2016).

Tugas keluarga juga harus mampu merawat anggota keluarga yang sakit. Tugas kesehatan ini untuk mengetahui sejauh mana keluarga memiliki kemampuan melakukan tindakan untuk pertolongan pertama pada penederia Pneumonia sebelum ke pelayanan 
http://journal.unpacti.ac.id/index.php/JPP

kesehatan. Dalam merawat anggota keluarga respon keluarga yang sakit sangat bervariasi mulai tidak melakukan apa-apa sampai dengan melakukan tindakan tertentu seperti mengobati sendiri, mencari fasilitas kesehatan tradisional, mencari pengobatan di warung obat, mencari pengobatan ke fasilitas kesehatan puskesmas atau rumah sakit (Nuretza et al., 2017).

Dalam melakukan upaya kesehatan. Keluarga juga memiliki tugas kesehatan untuk memelihara lingkungan, lingkungan rumah yang baik akan meningkatkan kesehatan keluarga dan membantu penyembuhan ketidak mampuan keluarga dalam memodifikasi lingkungan. Dalam hal ini kurangnya keluarga dalam memperhatiakn lingkungan rumah sangat besar resiko untuk terjadi penyebaran penyakit terhadap bayi hal tersebut bisa disebabkan karena terbatasnya sumber-sumber keluarga diantaranya keuangan kondisi fisik rumah yang tidak memenuhi syarat rumah sehat salah satunya kebersihan lingkungan sekitar rumah. pengolahan sampah dan kebutuhan pencahayaan di dalam rumah (Sitanggang et al.,2016).

Berdasarkan uraian di atas maka peneliti tertarik untuk mengadakan penelitian mengenai Hubungan Tugas Perawatan Kesehatan Keluarga Dengan Kejadian Pneumonia Pada Balita Di Wilayah Kerja Puskesmas Tinggede Kabupaten Sigi.

\section{BAHAN DAN METODE}

Penelitian ini merupakan penelitian survei analitik dengan pendekatan cross sectional study. Penelitian ini di lakukan di wilayah kerja Puskesmas Tinggede Kabupaten Sigi pada tanggal 01 September 31 Oktober 2020. Pengumpulan sampel mengunakan rumus Slovin dengan jumlah sampel 93 Responden. Pengumpulan data menggunakan data primer melalui teknik pengisian kuesioner dan wawancara dan Analisis data dilakukan secara univariat dan bivariat menggunakan uji chi square.

\section{HASIL}

Tabel 1. Karakteristik Responden Ibu.

\begin{tabular}{|c|c|c|}
\hline Karakteristik Ibu & $\mathbf{n}$ & $\%$ \\
\hline \multicolumn{3}{|l|}{ Umur } \\
\hline $18-20$ & 20 & 21,5 \\
\hline $21-23$ & 14 & 15,1 \\
\hline $24-26$ & 7 & 7,5 \\
\hline $27-29$ & 13 & 14,0 \\
\hline $30-32$ & 14 & 15,1 \\
\hline $33-35$ & 11 & 11,8 \\
\hline $36-38$ & 7 & 7,5 \\
\hline $39-41$ & 5 & 5,3 \\
\hline$>42$ & 2 & 2,2 \\
\hline \multicolumn{3}{|l|}{ Pendidikan Terakhir } \\
\hline SD & 18 & 19,3 \\
\hline SMP & 23 & 24,7 \\
\hline SMA & 32 & 34,4 \\
\hline Sarjana & 18 & 19,4 \\
\hline Tidak Sekolah & 2 & 2,2 \\
\hline \multicolumn{3}{|l|}{ Pekerjaan } \\
\hline PNS & 10 & 10,8 \\
\hline Petani & 8 & 8,6 \\
\hline Wiraswasta & 19 & 20,4 \\
\hline IRT & 56 & 60,2 \\
\hline \multicolumn{3}{|c|}{ Sumber: Data Primer, 2020} \\
\hline \multicolumn{3}{|c|}{ Tabel 2. Karakteristik Responden Balita } \\
\hline Karakteristik Balita & $\mathbf{n}$ & $\%$ \\
\hline \multicolumn{3}{|l|}{ Umur } \\
\hline $1-2$ & 49 & 45,2 \\
\hline $3-4$ & 29 & 31,2 \\
\hline 5 & 22 & 23,6 \\
\hline \multicolumn{3}{|l|}{ Jenis Kelamin } \\
\hline Laki-laki & 25 & 26,9 \\
\hline Perempuan & 68 & 73,1 \\
\hline
\end{tabular}

Sumber: Data Primer, 2020 
http://journal.unpacti.ac.id/index.php/JPP

Tabel 3. Analisis Bivariat Hubungan Tugas Perawatan Kesehatan Keluarga Dengan Kejadian Pneumonia Pada Balita Di Wilayah Kerja Puskesmas Tinggede Kabupaten Sigi.

\begin{tabular}{|c|c|c|c|c|c|c|c|}
\hline \multirow{2}{*}{$\begin{array}{c}\text { Tugas Perawatan Kesehatan } \\
\text { Keluarga }\end{array}$} & \multicolumn{4}{|c|}{ Pneumonia } & \multicolumn{2}{|c|}{ Total } & \multirow{2}{*}{ P value } \\
\hline & Pernah & $\%$ & Tidak & $\%$ & $\mathbf{n}$ & $\%$ & \\
\hline \multicolumn{8}{|l|}{ Mengenali Masalah } \\
\hline Kurang Mampu & 40 & 69,0 & 18 & 31,0 & 58 & 100,0 & \multirow{2}{*}{0,003} \\
\hline Mampu & 33 & 94,3 & 2 & 5,7 & 35 & 100,0 & \\
\hline \multicolumn{8}{|l|}{ Mengambil Keputusan } \\
\hline Kurang Mampu & 42 & 70,0 & 18 & 30,0 & 60 & 100,0 & \multirow{2}{*}{0,005} \\
\hline Mampu & 31 & 93,9 & 2 & 60,1 & 33 & 100,0 & \\
\hline \multicolumn{8}{|l|}{ Merawat Anggota Keluarga } \\
\hline Kurang Mampu & 36 & 66,7 & 18 & 33,3 & 54 & 100,0 & \multirow{2}{*}{0,001} \\
\hline Mampu & 37 & 94,9 & 2 & 5,1 & 39 & 100,0 & \\
\hline \multicolumn{8}{|l|}{$\begin{array}{l}\text { Memelihara lingkungan } \\
\text { Rumah }\end{array}$} \\
\hline Kurang Mampu & 35 & 66,0 & 18 & 34,0 & 53 & 100,0 & \multirow{2}{*}{0,001} \\
\hline Mampu & 38 & 95,0 & 2 & 5,0 & 40 & 100,0 & \\
\hline
\end{tabular}

Sumber: Data Primer, 2020

\section{PEMBAHASAN}

\section{Mengenali Masalah}

Berdasarkan hasil analisis terkait mengenali masalah kesehatan pneumonia bahwa terdapat 58 dengan frekuensi $(62,4 \%)$ yang mengatakan kurang mampu dalam mengenal masalah kesehatan pneumonia dan 35 dengan frekuensi $(37,6 \%)$ yang mengatakan mampu dalam mengenali masalah kesehatan pada pneumonia. Berdasarkan hasil uji statistik dengan menggunakan uji chi square diperoleh besaran $p$ value $=0,003$. Dengan demikian hasil $p$ value yang didapatkan lebih kecil dari nilai $\alpha(0,05)$ sehingga $\mathrm{H}_{0}$ ditolak. Artinya, ada hubungan yang bermakna antara pengenalan masalah kesehatan pneumonian dengan kejadian pneumonia pada balita. Hal ini menandakan bahwa secara umum pengetahuan responden tentang mengenali masalah kesehatan pneumonia masih cenderung belum terlalu baik. Sehingga peneliti berpendapat bahwa kurang familiarnya mereka dengan istilah pneumonia dan juga kurang banyaknya informasi terkait pneumonia di masyarakat. Peran ibu dalam rumah tangga memiliki peran lebih banyak dalam mengupayakan kesehatan keluarga. Maka dari itu, ibu perlu memahami seberapa dalam masalah yang dihadapi oleh keluarga untuk mengetahui suatu masalah yang dihadapi oleh keluarga.

Hal ini di dukung oleh penelitian (Aguti et al., 2018) dimana hasil penelitian menunjukkan bahwa lebih dari separuh ibu yang tinggal di pedesaan memiliki pengetahuan yang kurang memuaskan dari prates bahwa sekitar dua pertiga ibu telah 
meningkatkan pengetahuan mereka di daerah pasca-tes pedesaan. Di mana sangat penting ibu pedesaan memiliki pengetahuan yang sesuai tentang manifestasi klinis pneumonia, karena keterlambatan dalam mendeteksi tanda klinis merupakan hambatan yang berbahaya saat pencegah dan meningkatkan kematian akibat pneumonia masa kanak-kanak.

Peneliti berpendapat bahwa dalam mengenali masalah pneumonia ibu tidak hanya tergantung dari tingkat pendidikan saja tetapi juga dilihat dari faktor pekerjaan. Pekerjaan mungkin mempengaruhi tingkat pengetahuan keluaraga karena secara keseluruhan dalam penelitian ini keluarga bekerja sebagai ibu rumah tangga yang pekerjaannya mengurus rumah tangga dan sebagian besar waktunya di habiskan di rumah, sehingga informasi yang di dapatkan kurang luas dari keluarga atau ibu yang bekerja di luar rumah. Bekerja dapat memperoleh banyak pengalaman dan dari pengalaman tersebut akan memperoleh pengetahuan baru dan terus berkembang, sehingga keluarga yang tidak bekerja pada umumnya sedikit memperoleh pengalaman dan pengetahuan

Penelitian ini sejalan dengan penelitian (Kosai, 2017) yang mengatakan bahwa terdapat hubungan antara pendapatan keluarga dengan kejadian pneumonia $(\mathrm{HR}=1.11$; $\mathrm{CI}$ 95\% 1.02 hingga 1.20). Pekerjaan ibu di luar rumah pada kelompok kasus sebesar (42.9\%) dimana ibu yang bekerja di luar rumah lebih besar pendapatannya dibandingkan ibu yang bekerja di dalam rumah. Dari berbagai jenis pekerjaan yang dilakukan oleh ibu memiliki perbedaan dalam pendapatan yang diperoleh. Pendapatan yang rendah pada umumnya berkaitan erat dengan berbagai masalah kesehatan yang dihadapi, hal ini disebabkan karena ketidakmampuan dan ketidaktahuan dalam mengatasi berbagai masalah tersebut terutama dalam kesehatan.

Pendapat lain juga menerangkan bahwa tingkat pendidikan orang tua merupakan gambaran seberapa tinggi pengetahun yang dimiliki orang tua. Seperti halnya kemapuan dan keterampilan yang dimiliki orang tua tentu sesuai dengan tingkat pendidikan yang diikutinya. Pendidikan diyakini sangat berpengaruh terhadap kecakapan, tingkah laku dan sikap seseorang dan hal ini semestinya terkait dengan tingkat pendapatan seseorang. Artinya secara rata-rata makin tinggi tingkat pendidikan seseorang maka makin memungkinkan orang tersebut memperoleh pendapatan yang lebih tinggi (Kurniasari, 2017).

Hasil penelitian ini menunjukkan kelompok kasus dengan pendidikan tinggi sebesar (27.2\%) yaitu tingkat pendidikan SMA ke atas dan jumlah anak lebih yang dimiliki kelompok kasus sebesar (54.1\%). Rendahnya tingkat pendidikan tinggi ibu yang berakibat pada pendapatan yang diperoleh tidak menentu karena didasarkan pada jenis pekerjaan sebagian besar adalah petani dan buruh yang mengandalkan musim panen. Rendahnya tingkat pendidikan subjek penelitian berakibat pada banyaknya anak yang dimiliki yaitu lebih 
dari 2. Banyak anak dalam keluarga menimbulkan masalah kesehatan seperti kondisi rumah sesak memudahkan penularan penyakit infeksi, tertundanya anak mendapatkan perawatan karena faktor pendapatan keluarga rendah dan menimbulkan stres ibu dalam merawat anak (Kurniasari, 2017).

\section{Mengambil Keputusan}

Hasil analisis terkait pengambilan keputusan pneumonia bahwa terdapat 60 dengan frekuensi $(64,5 \%)$ yang mengatakan kurang mampu terhadap pengambilan keputusan dan 33 dengan frekuensi $(35,5 \%)$ yang mengatakan mampu terhadap pengambilan keputusan. Berdasarkan hasil uji statistik dengan menggunakan uji chi square diperoleh besaran $p$ value $=0,005$. Dengan demikian hasil $p$ value yang didapatkan lebih kecil dari nilai $\alpha(0,05)$ sehingga $\mathrm{H}_{0}$ ditolak. Artinya, ada hubungan yang bermakna antara pengaambilan keputusan dengan kejadian pneumonia pada balita. Kemampuan keluarga dalam mengambil keputusan terhadap anak pneumonia masih kurang peneliti berpendapat dimana masyarakat yang berada di wilayah kerja puskesmas tinggede dalam penelitian ini keluarga sudah banyak menggunakan pengobata secara medis di puskesmas dan masi ada sebagai lagi masih cenderung sulit untuk memilih alternatif pengobatan dan masi di dominasi dengan pengobatan secara tradisonal seperti halnya pijat bayi yang masi banyak masyarakat yang menggunakan sebagai alternatif pengobatan dikarenakan pijat bayi sangat membantu ibu dalam mengurus bayi yang mengalami sakit dan sesak nafas.

Hal ini sejalan dengan penelitian (Widyanti, 2016). bahwa dengan pijat bayi antara lain, mendapatkan hasil bahwa pada bayi yang di berikan perlakuan pijat bayi dan latihan gerak, pertumbuhan dan perkembangan lebih cepat di banding dengan bayi yang tidak di berikan pijat bayi dan latihan gerak. Disamping itu data klinis terbaru riset menunjukan bukti-bukti mengenai manfaat dari stimulasi sentuhan bayi dan ibu. Studi ini menunjukan bahwa pijat bayi $47 \%$ mengurangi masalah tidur bayi dan $100 \%$ ayah setuju bahwa pijatan bayi tersebut memberikan pengalaman positif yang luar biasa antar bayi dan orang tua. Pijat juga meningkatkan fungsi motorik dan memperkuat jaringan otot yang mengalami down sindrome termasuk 82\% perbaikan pada otot lengan dan kaki. Penelitian terkait dengan pijat bayi antara lain, mendapatkan hasil bahwa pada bayi yang di berikan perlakuan pijat bayi dan latihan gerak, pertumbuhan dan perkembangan lebih cepat di banding dengan bayi yang tidak di berikan pijat bayi dan latihan gerak.

Didapatkan dari hasil penelitian lain yang dilakukan oleh (Kurniati \& Indasari, 2018) bahwa bayi sehat lahir cukup bulan yang mendapatkan tindakan pijat bayi perkembangan mental-motor lebih signifikan di bandingkan dengan kelompok yang tidak dilakukan tindakan. Dampak positif yang ditimbulkan dari pijat bayi umumnya bayi 
yang mendapat pijatan secara teratur akan lebih rileks dan tenang. Melalui sentuhan pemijatan terhadap jaringan otot, peredaran darah dapat meningkat makin lancar, ataupun posisi otot dapat dipulihkan dan diperbaiki otomatis dapat meningkatkan fungsi-fungsi organ tubuh dengan sebaik-baiknya.

Sedangkan dampak negatif yang ditimbulkan bila pijat bayi dilakukan pemijatan dengan cara yang salah dan tidak sesuai dengan ketentuan medis. Efek samping dari kesalahan pemijatan diantaranya adalah pembengkakan, terdapatnya lebam, adanya rasa sakit pada bayi sehingga bayi menjadi rewel, pergeseran urat, cidera, bahkan bisa menyebabkan kematian pada bayi, Resiko pijat bayi biasanya disebabkan oleh kelalaian praktisi pijat dalam memijat, salah pijat, dan kurangnya pengetahuan pemijat. Di Indonesia pemijatan tidak hanya dilakukan bila bayi sehat, tetapi juga saat bayi sakit atau rewel dan sudah menjadi rutinitas perawatan bayi setelah lahir (Roesli, 2016).

Pelaksanaan pijat bayi ini dapat dipengaruhi oleh berbagai faktor. Faktor-faktor yang mempengaruhi pijat bayi yaitu terdiri dari faktor predisposisi (pengetahuan, Pendidikan, Pekerjaan, Umur, Sosial Budaya), faktor pendukung (sumber daya kesehatan), faktor pendorong (dukungan tenaga kesehatan, dukugan petugas kesehatan atau pelayanan kesehatan) dengan pengetahuan ibu yang luas akan berpengaruh pula pada keinginan ibu untuk dapat melakukan pijat bayi (Roesli, 2016)

\section{Merawat Anggota Keluarga}

Berdasarkan hasil penelitian, merawat anggota keluarga yang sakit bahwa terdapat 54 orang dengan frekuensi $(58,1 \%)$, yang mengatakan kurang mampu dalam merawat anggota keluarga di rumah dan 39 orang dengan frekuensi (41,9\%), yang mengatakan mampu merawat anggota keluarga di rumah. Berdasarkan hasil uji statistik dengan menggunakan uji chi square diperoleh besaran $p$ value $=0,001$. Dengan demikian hasil $p$ value yang didapatkan lebih kecil dari nilai $\alpha$ $(0,05)$ sehingga $\mathrm{H}_{0}$ ditolak. Artinya, ada hubungan yang bermakna antara merawata anggota keluarga yang sakit dengan kejadian pneumonia pada balita. Dari penelitian di wilayah kerja puskesmas tinggede peneliti mendapatkan masi banyak masyarakat yang masi belum mengerti dan memahami bagai mana merawat keluarga yang sakit di rumah seperti hal nya memberikan obat tanpa resep dokter atau memberikan jeruk nipis saat anak mengalami batuk, hal itu masi jauh dari kategori baik, di karenakan masyarakat masi banyak yang menggunakan obat tanpa resep dokter atau hanya membeli obat di warung atau apotik tanpa resep yang benar.

Hal ini di dukung oleh penelitian (Parvez et al., 2018) Dalam penelitian kami, sebagian besar ibu (94,4\%) menggunakan dua atau lebih pengobatan rumahan. Madu adalah obat yang paling umum digunakan untuk pneumonia $(82,4 \%)$ teh hijau adalah digunakan oleh $44,7 \%$ responden, sedangkan $43,2 \%$ responden ibu lebih menyukai pijat dada anak dengan 
Vicks. Sebuah studi yang dilakukan di Multan mengidentifikasi $53 \%$ dari ibu yang tidak mencari pertolongan dokter untuk merawat anak-anak mereka dari pneumonia hanya $21 \%$ yang memilikinya mengunjungi dokter keluarga yang memenuhi syarat, dan 19\% adalah pengobatan sendiri di rumah. Sikap keluarga dalam hal ini yang lebih memilih merawat balita di rumah menggunakan obat batuk yang tidak sesuai dengan syarat dari dokter. Tindakan keluarga yang kurang baik dalam merawat balita mengakibatkan terjadinya risiko lebih besar dan sangat rentan mengalami efek samping pada kesehatan balita, seperti terlalu banyak mengonsumsi obat paracetamol dan obat batuk dapat menyebabkan kerusakan hati, menyebabkan pusing, diare dan nyeri perut. yang diberikan dengan tidak sesuai petunjuk kesehatan.

Peneliti berpendapat bahwa sikap masyarakat yang lebih memilih obat batuk pada anak seperti memberikan Jeruk nipis, atau (citrus aurantifolia) mengandung minyak atsiri dan zat yang mampu mengendalikan otot pernapasan sehingga membantu saat batuk menyerang namun hal ini hanya mampu meredakan dan bukan menyembuhkan. Tugas kesehatan keluarga ini untuk mengetahui sejauh mana keluarga memiliki kemampuan melakukan tindakan untuk pertolongan pertama atau ke pelayanan kesehatan untuk memperoleh tindakan lanjutan agar masalah yang lebih parah tidak terjadi.

Sejalan dengan penelitian (Sri Suparni, 2016) menunjukan bahwa sebagai besar sikap ibu kurang dalam merawat balita pneumonia sebanyak $26(38,81 \%)$, dan sikap ibu yang tidak mampu merawat balita pneumonia 16 (61,5\%), sedangkan sikap ibu yang mampu merawat balita pneumonia 10 (38,5\%). Hasil analisis di peroleh data bahwa terdapat hubungan yang signifikan anatara sikap dengan kemampuan keluarga dalam werawat balita pneumonia dengan $p$ value $0,029(p<$ $0,05)$.

Sikap merupakan faktor penentu perilaku karena sikap berhubungan dengan persepsi, kepribadian dan motivasi, dengan demikian sikap merupakan faktor predisposisi yang memungkinkan terjadinya perubahan perilaku. Sikap yang buruk dalam penelitian ini bahwa responden kurang mendapatkan pendidikan dan pengetahuan yang akan mempengaruhi kurang memperolehnya stimulus untuk menentukan Bagaimana cara bersikap dalam merawat balita Pneumonia sikap adalah penilaian berupa pendapat seseorang terhadap stimulus atau objek dalam hal ini adalah masalah kesehatan termasuk perilaku merawat balita Pneumonia (Sitanggang et al., 2016).

\section{Memelihara Lingkungan}

Berdasarkan hasil penelitian dengan pemeliharaan lingkungan rumah bahwa terdapat 53 orang dengan frekuensi $(57,0 \%)$, yang kurang mampu dalam memelihara lingkungan rumah dan 40 orang dengan frekuensi $(43,0 \%)$, yang mampu dalam memelihara lingkungan rumah. Berdasarkan hasil uji statistik dengan menggunakan uji chi 
square diperoleh besaran $p$ value $=0,001$. Dengan demikian hasil $p$ value yang didapatkan lebih kecil dari nilai $\alpha(0,05)$ sehingga $\mathrm{H}_{0}$ ditolak. Artinya, ada hubungan yang bermakna antara memelihara lingkungan rumah dengan kejadian pneumonia pada balita. Pemeliharaan lingkungan rumah diwilayah kerja puskesmas tinggede meurut peneliti masi belum memenuhi syarat rumah sehat. Berdasarkan hasil wawancara diketahui bahwa anggota keluarga yang merokok adalah kepala keluarga. Anggota keluarga yang merokok memiliki kebiasaan merokok sejak lama dan tidak pernah berhenti dari kebiasan merokok. Hal ini turut menyumbangkan paparan gas $\mathrm{CO}$ di dalam rumah dan dapat menyebabkan penyakit paru-paru yang melemahkan daya tahan tubuh balita. Keberadaan perokok ini sebagian besar adalah kepala keluarga/ayah dari balita. Biasanya ayah balita merokok tidak jauh dari balita tersebut. Keterangan kepada responden saat peneliti bertanya beberapa di antaranya ayah balita merokok di dalam rumah. Sumber asap rokok di dalam ruangan (indoor) lebih membahayakan daripada di luar ruangan (outdoor), karena sebagian besar balita menghabiskan 60-90\% waktunya di dalam ruangan (Kartini dkk, 2020).

Hal ini didukung oleh penelitian (Nikmah et al., 2018). Kejadian pneumonia erat kaitannya dengan paparan asap rokok. Balita yang terpapar asap rokok berisiko 18,480 kali mengalami pneumonia dibandingkan dengan balita yang tidak terpapar asap rokok. Asap rokok yang mengandung zat-zat residu rokok dapat terhirup langsung oleh orang lain dan dapat tersebar di lingkungan hingga jarak 10 meter (Kartini dkk, 2019).

Asap rokok juga dapat menempel di baju maupun benda, seperti gorden, seprai, dan sebagainya yang kemudian dapat dihirup oleh orang lain. Zat-zat residu rokok tersebut biasa disebut dengan third hand smoke. Anak-anak dan balita yang tinggal di rumah dengan perokok aktif menjadi kelompok yang paling berisiko untuk terkena pajanan dari third hand smoke. Zat-zat residu rokok merupakan zat-zat yang berbahaya bagi tubuh apabila terpapar dalam dosis yang tinggi. Beberapa dari zat tersebut merupakan zat karsinogen, yaitu zat yang dapat menyebabkan kanker. Third hand smoke juga dapat mengakibatkan kerusakan organ seperti kerusakan fungsi liver dan jantung, gangguan pernapasan, juga perilaku hiperaktif pada anak yang tinggal di lingkungan third hand smoke. Pneumonia merupakan satu dari sekian banyak penyakit pernapasan yang disebabkan oleh third hand smoke pada anak-anak dan balita.

Selain itu jenis lantai rumah yang masih banyak menggunakan lantai acian atau belum menggunakan keramik atau tegel dan masih banyak masyarakat yang berada di huntara dan masi berada dalam tahap pembangunan rumah akibat gempa hal ini membuat sebagian masyarakat masi dalam proses pembangunan. Menurut peneliti saat ini masyarakat yang berada di wilayah kerja puskesmas tinggede masi sebagian masyarakat terutama di desa 
tinggede selatan dan sekitaran desa sunju yang masih sebagian besar menggunakan lantai rumah berjenis lantai acian dengan jenis dinding rumah yang tidak diplester dan sebagaiannya menggunakan dinding kayu.

Hal ini sejalan dengan penelitian (Krisnana et al., 2018), lantai rumah balita yang tidak permanen berisiko 2,635 kali lebih besar menderita pneumonia dibanding dengan balita yang tinggal di rumah dengan lantai yang permanen. Rumah yang sudah berubin memiliki kelembapan yang rendah jika dibandingkan dengan rumah yang lantainya belum berubin. Balita yang sering bermain di lantai yang belum berubin atau lantainya belum memenuhi syarat akan mempunyai risiko terkena pneumonia lebih tinggi. Jenis lantai tanah akan menyebabkan kondisi dalam rumah berdebu. Keadaan berdebu ini sebagai salah satu bentuk terjadinya polusi udara dalam rumah (indoor air pollution) (Kartini dkk, 2019).

Debu dalam udara apabila terhisap akan menempel pada saluran napas bagian bawah yang menyebabkan pergerakan silia menjadi lambat, sehingga mekanisme pembersihan saluran pernapasan menjadi terganggu. Jika mekanisme ini terganggu dapat mengakibatkan balita kesulitan bernapas. Oleh karena itu, lantai perlu dilapisi bahan kedap air (disemen, dipasang tegel atau keramik).

Menurut penelitian peneliti meihat sebagian besar responden memiliki ventilasi udara di rumah dan sebagian lagi tidak memiliki ventilasi udara dan hanya mengandalkan lubang-lubang dinding papan. Sebagian besar responden memiliki jendela di dalam rumah dengan jumlah yang berbedabeda, ventilasi udara dalam rumah sangat di butuhkan untuk mengurangi dan menghilangkan polutan di udara di dalam ruangan

Hal ini sejalan dengan penelitian (Budhathoki et al., 2020). Rumah yang tidak memiliki ventilasi udara 6.44 kali berisiko mengalami pneumonia dibandingkan balita yang memiliki ventilasi rumah sebab didalam ruangan yang tertutup, udara tidak dapat keluar dengan mudah. Hal ini membuat udara berpolutan tetap berada di dalam ruangan dan akan terus bertambah. Situasi tersebut dapat berpengaruh pada kesehatan manusia di dalam ruangan tersebut. Ventilasi sangat penting untuk menghilangkan udara yang berpolutan tersebut.

\section{KESIMPULAN DAN SARAN}

Berdasarkan hasil penelitian tentang Hubungaan Tugas Perawatan Kesehatan Keluarga dengan Kejadian Pneumonia Pada Balita di Wilayah Kerja Puskesmas Tinggede Kabupaten Sigi didapatkan kesimpulan yaitu, terdapat hubungan antara mengenali masalah kesehatan pneumonia, mengambil keputusan, merawat anggota keluarga, memelihara lingkungan rumah dengan kejadian pneumonia pada balita di Wilayah Kerja Puskesmas Tinggede Kabupaten Sigi.

Dalam tugas perawatan kesehatan keluarga, keluarga perlu memahami informasi 
mulai dari penyebap dan gejala pneumonia. Mampu mengambil keputusan alternative pengobatan seperti ke rumah sakit, puskesmas, atau ke dukun. Merawat anggota keluarga seperti memberikan kompres saat anak demam dan memberikan obat dengan resep dokter, memelihara lingkungan rumah dengan memperhatikan syarat rumah sehat.

\section{DAFTAR PUSTAKA}

Anggina, Y., Lestari, Y., \& Zairil, Z. (2019). Analisis Faktor yang Mempengaruhi Penanggulangan HIV/AIDS di Wilayah Kerja Dinas Kesehatan Kabupaten Padang Pariaman Tahun 2018. Jurnal Kesehatan Andalas, 8(2), 385. https://doi.org/10.25077/jka.v8.i2.p385393.2019Aguti, B., Kalema, G.,

Lutwama, D. M., Mawejje, M. L., Mupeyi, E., Okanya, D., Nekaka, R., \& Gavamukulya, Y. (2018). Knowledge and Perception of Caregivers about Risk Factors and Manifestations of Pneumonia among Under Five Children in Butaleja District, Eastern Uganda. Microbiology Research Journal International, 25(3), 1-11. https://doi.org/10.9734/mrji $/ 2018 / 44179$

Budhathoki, S. S., Tinkari, B. S., Bhandari, A., Dhimal, M., Zhou, H., Ghimire, A., Basnet, O., Wrammert, J., \& Kc, A. (2020). The Association of Childhood Pneumonia with Household Air Pollution in Nepal: Evidence from Nepal Demographic Health Surveys. Maternal and Child Health Journal, 24(s1), 4856. https://doi.org/10.1007/s10995-02002882-x

Ceria, I. (2016). Hubungan Faktor Risiko Intrinsik Dengan Kejadian Pneumonia Pada Anak Balita. Pneumonia: The Forgotten Killer of Children, WHO, New York., 11(4), 1907-3887.
Dinas Kesehatan Provinsi Sulawesi Tengah. (2019). Profil Dins Kesehaan Profinsi Sulawesi Tengah.

Kartini dkk, 2020. Hubungan Antara Perilaku Orang Tua Tentang Infeksi Saluran Pernapasan Akut (ISPA) Dengan Kekambuhan ISPA Pada Balita di Wilayah Kerja UPTD Puskesmas Wukir, Jurnal Promotif Preventif, 2(2): 27-34

Kartini dkk, 2019. Pengaruh Kondisi Fisik Rumah Dengan Kejadian ISPA Pada Anak Usia 1-12 Tahun di Wilayah Kerja Puskesmas Tarakan Kota Makassar, Jurnal Promotif Preventif, 1(2): 1-9

Kementrian Kesehatan RI. (2018). Data dan Informasi Profil Kesehatan Indonesia tahun 2019.

Kurniati, D., \& Indasari, E. (2018). Terapi Pijat Bayi Di Rumah Sakit Kartini Cipulir Jakarta Selatan. Jakhkj, 4(2).

Kosai H, Tamaki R, Saito M, Tohma K, Alday PP (2017). Incidence and Risk Factors of Childhood Pneumonia-Like Episodes in Biliran Island, 1-19. doi: 10.1371/journal.pone.01 25009.

Kurniasari AD (2017). Hubungan Antara Tingkat Pendidikan, Pekerjaan dan Pendapatan Orang Tua Dengan Status Gizi Pada Siswa SD Hangtuah 6 Surabaya, Jurnal Pendidikan Olahraga dan Kesehatan. 5(2): 164-170.

Krisnana, I., Pratiwi, I. N., \& Kristiani, N. K. D. (2018). Analysis of Maternal Behavior in the Prevention of Pneumonia in Children Using WHO Behavioral Determinant Approach. January, $\quad$ 65-70. https://doi.org/10.5220/0007055100650 070

Nuretza, J. A., Winarni, S., Diponegoro, U., \& Diponegoro, U. (2017). Hubungan Antara Perilaku Keluarga Dan Kondisi Lingkungan Dalam Rumah Dengan Kejadian Pneumonia Pada Anak Balita Di Wilayah Kerja Puskesmas Halmahera 
http://journal.unpacti.ac.id/index.php/JPP

Kota Semarang. Jurnal Kesehatan Masyarakat (e-Journal), 5(5), 696-705.

Nikmah, A., Rahardjo, S. S., \& Qadrijati, I. (2018). Path Analysis on the Effect of Ambient Smoke and Other Risk Factors on Pneumonia among Children Under Five in Karanganyar, Central Java. 70. https://doi.org/10.26911/mid.icph.2018. 01.07

Parvez, M., Wiroonpanich, W., \& Naphapunsakul, M. (2018). The effects of educational program on child care knowledge and behaviors of mothers of children under five years with pneumonia. Bangladesh Journal of Medical Science, 9(3), 136-142. https://doi.org/10.3329/bjms.v9i3.6468

Roesli, U., 2016, Pedoman pijat bayi. Jakarta: PT. Trubus Agiwidya

Sitanggang, Y. A., Qur'aniati, N., \& Krisnana, I. (2016). Hubungan Penatalaksanaan Tugas Kesehatan Keluarga Dengan Kejadian Ispa Pada Balita Di Wilayah Kerja Puskesmas Martapura. Pediomaternal Nursing Journal, 2(2).
Sri Suparni, 2016, Faktor Yang Mempengaruhi Kemampuan Keluarga Dalam Merawat Balita Dengan Pneumonia Di Wilayah Kerja Puskesmas Banjarmanggu Kabupatem Banjarnegara, Skripsi, Program Studi Ilmu Keperawatan Fakultas Ilmu Kesehatan Universitas Muhammadiyah Purwakerto.

Widagdo. (2017). Masalah tatalaksana penyakit anak dengan demem. Jakarta. Mitra Cendekia.

Widyawati. 2016, Hubungan Karakteristik Ibu dengan Pengetahuan tentang pijat bayi di wilayah kerja Puskesmas Gribig. Jurnal Kebidanan, Malang. 